\title{
Triple helix and residential development in a science and technology park: the role of intermediaries
}

Friederike Bellgardt, Jürgen Gohlke ${ }^{*}$, Henriette Haase, Roman Parzonka ${ }^{*}$ and Juliane Schicketanz

*Correspondence:
golkejue@hu-berlin.de;
parzonkr@hu-berlin.de
Geographisches Institut,
Humboldt-Universität zu Berlin,
Unter den Linden 6, Berlin 10099,
Germany

* Correspondence golkejue@hu-berlin.de; Humboldt-Universität zu Berlin, Germany

\begin{abstract}
Science and technology parks are the three-dimensional expression of the ever-growing importance of innovation, creativity and knowledge as economic resources. Science cities are the next step up: knowledge-based forms of urban settlement. Thanks to a housing project currently being developed, the Berlin-Adlershof science and technology park is undergoing a gradual transformation into a science city. Taking Berlin-Adlershof as a case study, this article examines the extent to which the triple helix approach can be usefully applied to the planning process of a housing project. The triple helix approach has hitherto been mainly used to study the organizational arrangements of industry, university and government, arrangements that are seen to foster processes of innovation. Drawing upon this tenet, the present study focuses on the socio-cultural aspects of urban development in the context of science cities, aspects which have so far received little attention in triple helix research. The aim is to use the triple helix concept to assess the innovative character of the gradual transformation of a science and technology park into a science city through residential development. Within the framework of this study, semi-structured expert interviews with representatives relevant to the Adlershof development were conducted between November 2013 and January 2014. The study showed that the triple helix approach cannot be usefully applied to the interaction of actors involved in residential development in science cities. Alternatively, we propose a model of interaction that highlights the pivotal role of the intermediary in the planning process.
\end{abstract}

Keywords: Triple helix; Science and technology park; Science city; Berlin-Adlershof; Residential development

\section{Multilingual abstracts}

Please see Additional file 1 for translation of the abstract into the five official working languages of the United Nations and Portuguese.

\section{Introduction and research question}

Science and technology parks are the three-dimensional expression of the evergrowing importance of innovation, creativity and knowledge as economic resources. Here, in highly concentrated form, the spatial proximity of different actors allows for efficient organization of the production of knowledge (and science). Actors operate in ideal conditions for fast, informal processes of exchange, evaluation and communication, 
and this contributes substantially to the genesis of creative and innovative processes (Bathelt et al. 2011). Science and technology parks are extremely important in the regional context, giving the surrounding area an economic boost (Handrich et al. 2008: 41). On a global level, they are in constant competition with each other.

Science cities are the next step up: knowledge-based forms of urban settlement (Kühn 2003). In a science city, in addition to the establishment of science-based institutions, the socio-cultural areas of housing and leisure are integrated into the urban development context. Their design is based on an idealized image of cities as places of innovation, with a particular focus on characteristics that stimulate the genesis of innovation, creativity and new knowledge (Heßler 2007: 147f.). At the same time, however, planners deliberately omit other quintessentially urban characteristics such as contradictions, complexity, disorder, social and political conflicts, and environmental problems (ibid.: 148). According to Heßler, the "[...] complexity of the city as a social form, as a form of human coexistence [is] set aside" in science cities (ibid.: 147, translated).

The Berlin-Adlershof science and technology park is undergoing a gradual transformation into a science city, thanks to a housing project currently under construction, Wohnen am Campus (Living on Campus). The expansion of the previous range of functions to include housing, a function inherent to cities, is a step towards the realization of the "[...] most comprehensive attempt at a planned mix of uses" (Kühn 2003: 147, translated), something which cannot yet be found in reality. This development can be understood as something novel and innovative.

The triple helix research approach focuses on the development of innovations, which it considers to be the result of the intersecting relationships of the three groups of actors (helices) from the spheres of industry, university and government (Leydesdorff and Etzkowitz 1996). So far, empirical research has disregarded socio-cultural aspects in the urban development context of science cities. The present study takes this as its starting point and attempts to explore the innovative character of the transformation of a science and technology park into a science city, in the terms of the triple helix concept. The aim is to use the case study of Berlin-Adlershof to test the applicability of the triple helix approach to the process of planning a housing project in a science and technology park.

\section{Literature review: triple helix}

Originally conceived by Etzkowitz and Leydesdorff, the triple helix research approach has continued to evolve over the years (Leydesdorff and Etzkowitz 1996, 1998; Etzkowitz and Leydesdorff 1997, 2000; Etzkowitz 2003; Leydesdorff 2000, 2013). At its core, it postulates a new institutional foundation for the development of innovations. As in a triple helix, the complex process of creating innovations no longer takes place in a single institution, but in the form of trilateral networks made up of the interacting helices of industry, university and government (Fogelberg and Thorpenberg 2012; Hotz-Hart and Rohner 2014: 43). According to this understanding, the helices become ever more closely interwoven, eventually fusing into a triple helix structure (borrowed metaphorically from biology) (cf. Etzkowitz and Leydesdorff 1997; Ortiz 2013: 96; Rammert 2007: 192).

In the relational network of the triple helix, each of the three helices is ascribed a specific role. Universities, as actors in the field of science, are described here as primary institutions (Etzkowitz 2013: 487). Gibbons et al. (1994) discern a change in the significance of the helices and distinguish between modes $I$ and II. 
Traditionally, the role of universities in the social and economic system was subordinate to that of industry and government. The strict separation of research and practical application, and the related linear production of knowledge in academic disciplines, is referred to as mode I. Here universities functioned as neutral support structures for innovation (Etzkowitz 2003), producing fundamental knowledge, providing research findings and training personnel for higher-ranking institutions.

Today, however, universities occupy a key position in innovation processes. As part of the second academic revolution (Etzkowitz 2003: 294), the emergence of new, heterogeneous knowledge producers may have deprived universities of their monopoly, but in return they have considerably expanded their remit, well beyond their basic functions of research and teaching. Gibbons et al. (1994) regard this development as mode II of knowledge production. Universities produce knowledge in transdisciplinary processes, then utilize and market it; they establish and support spin-offs, and perform "quasi entrepreneurial functions" (Ortiz 2013: 96, translated), hence the term entrepreneurial universities (Etzkowitz 2003, 2013; Etzkowitz et al. 2000; Etzkowitz and Zhou 2008). Entrepreneurial universities strive to use the knowledge they generate to actively participate in social and economic developments. As a result, they are regarded as equal-ranking primary institutions. They are actively involved in the utilization and capitalization of the knowledge they have generated and play a key role in the networks that foster innovation: the communicative, interactive networks between industry and government. The boundaries of each institution's sphere of influence are in flux and are constantly being rebalanced (Leydesdorff and Etzkowitz 1998: 195; Leydesdorff 2000: 243).

It is not just universities which are changing, expanding their traditional range of functions to include entrepreneurial activity, and thus becoming more like industrial enterprises. At the same time, companies are becoming increasingly similar to universities, with industrial actors incorporating typically academic activities. These include maintaining their own research and development facilities, constantly increasing the skill level of their staff by offering training and professional development, and sharing knowledge with each other. The high degree of overlap between the institutions leads to a mutual exchange of skills in the areas usually covered by the other helices; in the terminology of the triple helix concept, this is referred to as hybridization or taking the role of the other (Etzkowitz 2003: 295; Ranga and Etzkowitz 2013: 238 f.). At the point where the spheres of the different actors intersect, the simultaneous presence of competition and cooperation becomes 'co-opetition'.

Figure 1 shows the diversity of the institutional arrangements which can arise from different relationships between the three helices. In the statist model (Figure 1a), industry and universities are organized by a central government, and their mutual relationships are strictly regulated. The laissez-faire model (Figure 1b) describes the three spheres as clearly separate from one another. Interaction between them is very limited. The institutions are closest to each other in the triple helix configuration devised by Etzkowitz and Leydesdorff (2000: 111) (Figure 1c). Here the areas of influence of the three helices are so diffuse that new organizational arrangements and connections emerge at the points where the three spheres intersect (innovation in innovation). These might include collaborative R\&D projects or "hybrid" forms of organization which support companies during the start-up period (incubators), provide venture capital or act as intermediaries, promoting the development and collaboration of an entire site (Etzkowitz 2003: 308; Ranga and Etzkowitz 2013: 244; Rodrigues and Melo 2013: 1677). 


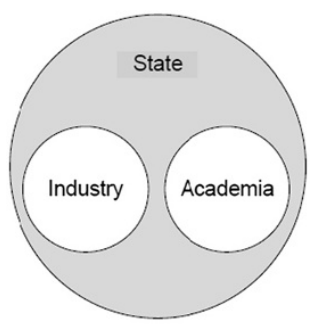

(a)'Statist'

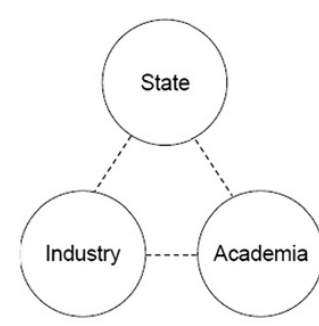

(b) 'Laissez-faire'

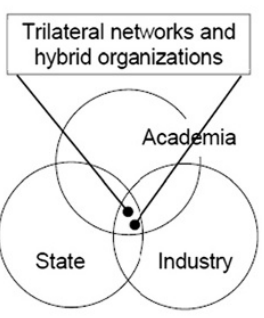

(c) 'Balanced'

Figure 1 Three models of a triple helix (Ranga and Etzkowitz 2013: 239). (a) Statist. (b) Laissez-faire. (c) Balanced.

The triple helix should not be understood as a generally valid theoretical structure, but rather as a systemic approach "[...] which creates a common analytical framework for the mostly isolated case studies in this area" (Ortiz 2013: 50, translated). Content-wise, the spectrum of previous empirical studies ranges from work emphasizing the role of entrepreneurial universities in the internationally significant innovation cluster of Silicon Valley (Kitagawa 2005) to the restructuring of national innovation clusters. In the regional context, empirical studies have dealt with such topics as specific activities carried out by universities to support start-ups and develop regional clusters (Etzkowitz and Zhou 2008), and analysis of the restructuring of former industrial areas (Fogelberg and Thorpenberg 2012).

\section{Specific research question and research area}

The triple helix approach is primarily used to examine the organizational arrangements of the different helices, arrangements which are directly connected to different processes of innovation. While the emergence of science and technology parks has already been the object of isolated studies (Kitagawa 2005; Etzkowitz and Zhou 2008; Fogelberg and Thorpenberg 2012), their subsequent development into science cities has so far been overlooked. The present study takes this as its starting point, focusing on the socio-cultural aspects in the urban development context of science cities, aspects which have so far been disregarded in research on the triple helix model. The aim is to use the triple helix research approach to examine the innovative content of the gradual transformation of a science and technology park into a science city (Figure 2).

\section{Hypotheses}

The main research hypothesis for the present study, $\mathrm{H}$ 1, is as follows:

H1: The triple helix approach can be usefully applied to the interaction of actors involved in residential development in science cities.

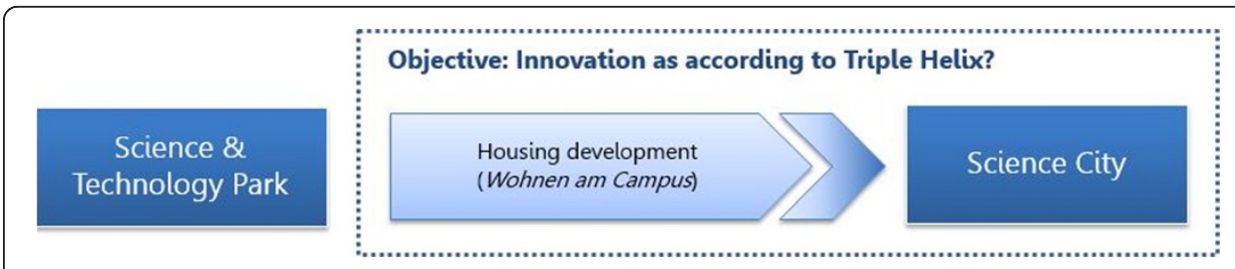

Figure 2 Gradual transformation into a science city (authors' design). 
Two subordinate hypotheses (H1.1 and H1.2) were derived from this main hypothesis; acceptance of these is a fundamental condition for a positive response to $\mathrm{H} 1$ :

H1.1: There is interaction between actors of government, university and industry to the effect of developing housing in science cities. (Henceforth known as interaction hypothesis) H1.2: Actors from government, industry and university interact on an equal footing. (Henceforth known as equality hypothesis)

In recognition of recent empirical work on the triple helix that has tended to describe intermediating organizations (Metcalfe 2010) or organization organizers (Ranga and Etzkowitz 2013), a third sub-hypothesis acknowledging the importance of intermediaries is put forward. An intermediary can be understood as a hybrid organization, formed endogenously from the institutional overlap between the three spheres of industry, university and government. Thus, the question arises as to whether an intermediary is also needed for the development of housing in science cities (H1.3):

H1.3: An intermediary is needed to coordinate the interaction of actors from government, industry and university. (Henceforth known as intermediary hypothesis)

Within the framework of the study, the hypotheses formulated above were tested on the housing project Wohnen am Campus in the Berlin-Adlershof science and technology park. The idea is that the construction of housing here will give this high-tech cluster an urban character. The present study investigates whether the planning process for the various housing options can be conceived as an innovative product in terms of a triple helix model. Before outlining the method, a brief introduction to the site selected for study will give a better understanding of the relationships between the actors in the planning process.

\section{Study site: Berlin-Adlershof}

Berlin-Adlershof is an integrated industrial, scientific and media site, and the biggest hightech cluster in Germany (Handrich et al. 2008: 41). It is located in the Treptow-Köpenick district (Bezirk) in southeastern Berlin, on the southwestern side of the Adlershof subdistrict (Ortsteil). Since 1994, the Johannisthal/Adlershof area has been designated as the object of one of seven urban development programmes in Berlin by Berlin's Senate Department for Urban Development and the Environment (see Figure 3).

This instrument for urban development planning allows for co-ordinated development on the roughly 480-hectare site (SenStadtUm 2013a: 32). Private land owners and the municipality share the obligation to rehabilitate the land and build on it according to planning law requirements (ibid.). Adlershof Projekt GmbH (prior to 2004: Berlin Adlershof Aufbaugesellschaft mbH (BAAG)) serves as the urban development agency and trustee of the federal state of Berlin. It is responsible for the development and marketing of the land owned by the state and for measures to clear this land and provide infrastructure. In terms of ownership, it is a $100 \%$ subsidiary of the second development actor on the site, WISTA Management GmbH. This differs from Adlershof Projekt $\mathrm{GmbH}$ in that it is more strongly focused on economic policy goals and has a standardized marketing strategy for land which is ready for development (SenStadt 2007: 3). In the last 15 years or so, WISTA Management GmbH has undergone a process of 


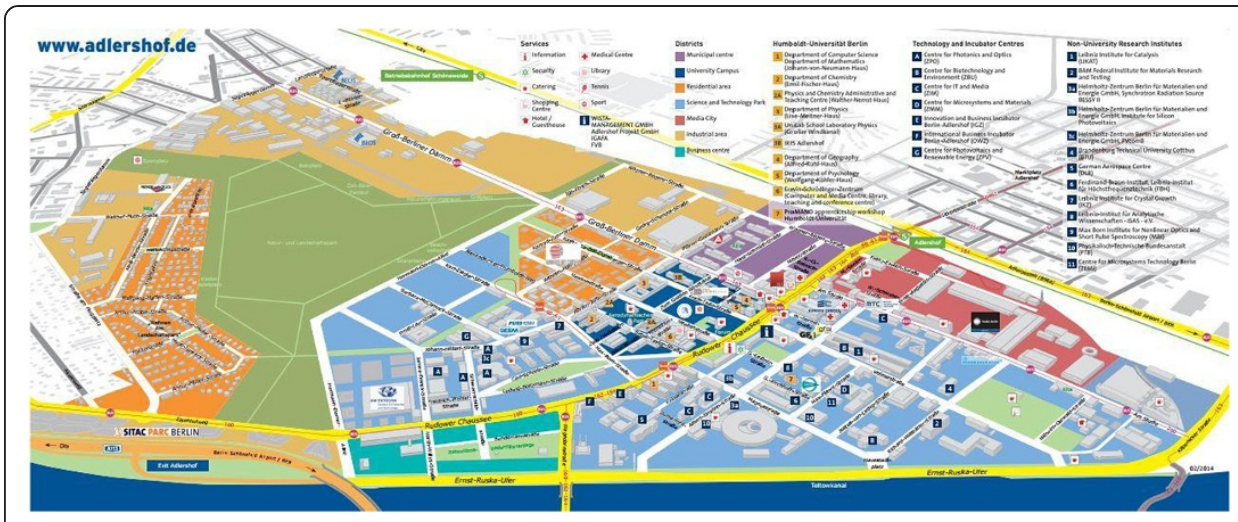

Figure 3 Area covered by the urban development project Berlin-Adlershof (๑ WISTA-MANAGEMENT GMBH - www.adlershof.de).

professionalization and made a major contribution to the present state of development by promoting networks of university and industry, supporting national and international collaborations and running PR operations for the whole development area (Mieg and Mackrodt 2010; Mieg 2012).

The historical development of the site explains the present-day international importance of this science and technology park. After 1945, the Akademie der Wissenschaften (Academy of Sciences) was located here; it brought with it many applied research facilities and still shapes the corporate structure of the location today. The decision in 1991 to relocate the natural science departments of the Humboldt-Universität zu Berlin from Berlin-Mitte to Berlin-Adlershof contributed substantially to the development of the present site. From 1998 to 2003, the departments of computer science, mathematics, chemistry, physics, geography and psychology all moved site.

An evaluation carried out by town and country planners in 1993 produced a consensus plan. This 'use-related development plan' still exists in an updated form today and establishes the parameters and provisions for a mixed urban structure for future site development planning (SenStadt 2007: 5). The initial focus of development in the area was the creation of a knowledge-based economy. Only later could aspirations to urban character - the ambition to turn the site into an integrated city (Mieg 2012: 256) - be taken into account. This ambition is reflected in the site's slogan, Stadt in der Stadt (translates as "city within the city", Hölmer 2013: 4; Müller 2013: 1). The current move to supplement knowledge-based institutions with housing is a central objective of urban development and an important step towards the realization of an integral mix of uses. This was already envisaged in 1994, when the Johannisthal/Adlershof urban development programme was announced (SenStadtUm 2013a: 3).

The Wohnen am Campus area is a 14-hectare zone in the Berlin-Adlershof science and technology park, on which 14 different residential projects with a total of 1,300 units of housing are currently being built. They vary in terms of building types and forms of ownership, creating a mixture of urban villas, town houses, blocks of flats and student housing. The investors are housing cooperatives (Wohnungsbaugenossenschaften), urban housing associations (Wohnungsbaugesellschaften), private developers (Bauträger) and cohousing group (Baugruppen) (SenStadtUm 2013a: 20). Wohnen am Campus has been 
created to supplement the area of detached housing which already exists, Wohnen am Landschaftspark. This, due to its position on the edge of the development area, is not integrated into the future science city.

\section{Methodology}

The selection of the case study, Wohnen am Campus, in the study area is based on the assumption that this is a site of activity both for the enterprises and research institutes established in the Berlin-Adlershof science and technology park and for political actors. It is assumed that the now-completed planning process for the housing construction project will have involved interaction between actors from the three spheres (interaction hypothesis H1.1).

In the case study, the three spheres of the triple helix are represented by the following:

1. All commercial enterprises based in this location or otherwise active here (industry),

2. University and non-university research institutes (science),

3. The Senate Department for Urban Development and the Environment (SenStadtUm) and the administrative district (Bezirk) of Berlin TreptowKöpenick (government).

We assume that interaction between the actors is based on an equal footing (equality hypothesis H1.2). Accordingly, interviewees were chosen so as to equilibrate opinions and yield the most accurate picture of the planning process. To that end, representatives of each sphere were asked about their contribution to the idea and planning process for the Wohnen am Campus project. The government helix was represented by the members of the Senate Department for Urban Development and the Environment (SenStadtUm) who were responsible for the urban development programme. For the helix of industry, interviews were carried out with a board member of the Technologiekreis Adlershof e.V. (TKA), the association of companies based here, and with an external representative and investor in a student housing project located on the site (Studentendorf Schlachtensee eG). In an attempt to avoid overemphasizing the importance of investors at the expense of other actors, and because we assumed the contribution of investors to the planning process to be relatively uniform, we chose to only interview one housing developer. For the helix of university, given that the role of the university is particularly emphasized in the triple helix model, a representative of the Humboldt-University of Berlin (HU Berlin) with responsibility for Adlershof was interviewed. Another important player in the planning process for the housing construction project is Adlershof Projekt GmbH (AP). As the trustee and marketing body for the individual sites and the overall location, it was directly involved in the planning for the housing construction project and is therefore included among the interviewees.

Within the context of this study, five semi-structured expert interviews were carried out with these different representatives between November 2013 and January 2014. These were then used to test the research hypotheses. The interviews focused on the planning process for the housing construction project. In addition to questions about 
individuals and institutions, the interviewees were asked for their views on the involvement of actors from the three helices in the planning process.

\section{Findings}

In order to be able to objectively consider the study hypotheses, it was necessary to ascertain how the actors from government, industry and university perceived the planning process for the Adlershof housing project Wohnen am Campus. A comparative analysis of the semi-structured expert interviews with regard to the selected main and subordinate hypotheses has yielded the following findings.

\section{Interaction hypothesis}

The first finding is that interaction did take place between actors from government, industry and university for the purpose of residential development in the BerlinAdlershof science and technology park. In 2009, a workshop on the Wohnen am Campus project was held with actors from government, industry and university. The workshop was attended by representatives of the Senate Department for Urban Development and the Environment, the district office (Bezirksamt) of Treptow-Köpenick, the Humboldt-University of Berlin, the IGAFA (Joint Initiative of Non-University Research Institutes in Adlershof), and also private developers, architects, planning offices and Adlershof Projekt GmbH. The focus was on four thematic areas: (1) the urban development framework, (2) the energy concept, (3) considerations relating to the real estate market and (4) the potential for marketing to co-housing groups.

(1) In the discourse on the urban development framework for the new residential area, participants agreed on an "urban ambience", to be achieved by a wide range of dwelling types (SenStadt 2009: 6, translated). A large number of building types from urban villas and town houses to blocks of flats and student housing - is designed to appeal to a broad range of prospective residents (ibid.: 3). According to the statements of the interviewees, the infrastructure links to the inner city via the direct motorway connection and stops or stations in the local transport network were emphasized as a factor which would make the science city more attractive as a place to live. The target group is not explicitly the employees and students already on the site.

(2) To supply energy to the new residential area, the decision was made to create an energy efficiency plan, aimed at cooperation with locally based companies from the energy supply sector (SenStadt 2009: 11).

(3) From a real estate point of view, the workshop participants state that the planned housing project is located in an area with a stable social structure, close to recreational spaces such as the Landschaftspark, and has good infrastructure links (SenStadt 2009: 14). In the context of the city as a whole, Berlin is experiencing population growth and a simultaneous shortage of available homes in the inner city (SenStadt 2009: 13). Young families in particular find it increasingly difficult to secure homes suitable for families in the city centre. This is exacerbated by the low level of new building activity, which will not be able to prevent further housing shortages in the immediate future. The market situation in the Treptow-Köpenick district is characterized by a low rate of vacancy, below-average rents and a high 
proportion of elderly residents and families. There is potential for developing ownership models for families and senior citizens, rental property for people employed on the site short-term and student housing.

(4) According to the assessment of the participants, one area of potential for the housing project is development by a co-housing group. The prerequisite for this is a firm basic concept and development concept for the area (SenStadt 2009: 16).

Two further collaborations - bilateral interactions relating to residential planning also need to be highlighted. In 2005, in preparation for the building project, the helices of government and university negotiated over the availability of land on the site of the future housing project. The Humboldt-University of Berlin was entitled to reserve areas in the immediate vicinity of its locally based institutes. These reserve areas were to be redesignated by the Senate Department for the completion of the housing project. The Humboldt-Universität was happy to cooperate. Its interest in the implementation of the housing project is explained partly by the increased attractiveness this is expected to give the campus and partly by the university's hope that the establishment of a student hall of residence will cover the housing requirements of its students. A second bilateral interaction in the planning process was identified between the helices of industry and university. The Humboldt-University of Berlin entered into an agreement with the investor of the planned student hall of residence, in which the HU Berlin pledged to fill 120 hall of residence places, including a penalty clause if the places were not occupied. The interviewees also indicate that the topic of the housing development is often mentioned at informal encounters such as summer fêtes, phone conversations and meetings arranged at short notice.

In the analysis carried out for this study, the workshop organized in the course of the planning process is understood as a one-off trilateral interaction and serves to confirm the interaction hypothesis (H1.1).

\section{Equality hypothesis}

When the expert interviews were analysed in terms of equality between actors from government, industry and university in the context of the above-mentioned interaction, the government helix turned out to be dominant. In the course of the planning process for Wohnen am Campus, the planning law measures were administered by the Senate Department for Urban Development and the Environment and the Treptow-Köpenick District Office. It was also possible to establish that Adlershof Projekt $\mathrm{GmbH}$, as trustee and development agency for the land belonging to the federal state, also acts on behalf of the Senate Department on the site. The starting point is the establishment of an urban development programme on the premises of the science city, which makes it possible 'to develop an area as a single project, actively, quickly, and with a clear goal focus, and to impose the same obligations on owners and local authorities' (SenStadt 2007: 5, translated). In its capacity as trustee, Adlershof Projekt GmbH markets sites owned by the federal state to prospective investors throughout the development area. While the Wohnen am Campus housing project is underway, Adlershof Projekt $\mathrm{GmbH}$ accompanies the prospective buyers from sale negotiations to the beginning of construction. In its capacity as development agency, it is also charged with expanding the infrastructure. 
Within the framework of the urban development programme, the Senate Department has authority in terms of planning law. This includes financial controlling and urban land-use planning. Given the budgetary constraints faced by the federal state of Berlin, financial controlling serves to contain the costs of providing infrastructure to the area prior to construction. At the Adlershof location, the issuing of planning permits falls to the civil engineering and road construction department of the Treptow-Köpenick District Office, while the Senate Department is responsible for changes to the zoning plan, the establishment of design guidelines for developers, and negotiations with the HumboldtUniversity of Berlin over the availability of reserve areas.

Compared to government, the other helices play a subordinate role in the interaction process on the site. A representative of local industry does not see the creation of housing as being within his company's sphere of interest and does not discount the possibility that the housing might be used by his employees. The university can, according to its own statements, only contribute to the success of the housing project to a very small extent. The reason for this is a shortage of financial and human resources, which prevents any extensive form of participation and collaboration.

Based on the statements of the experts, then, the trilateral interaction regarding the residential development in Berlin-Adlershof did not involve all three spheres working together on an equal footing. Decisions about the residential development were made by the government helix right from the start. The equality hypothesis can therefore not be confirmed.

\section{Intermediary hypothesis}

Intermediaries are 'those organizations that are (intentionally) situated between the state, industry, and higher education' (Metcalfe 2010: 507). According to this definition, analysis of the expert interviews suggests that Adlershof Projekt GmbH can be understood as an intermediary in relation to the residential development on the site under study. As a 100\% subsidiary of WISTA Management GmbH, it carries out mandatory tasks such as the development, urban land-use planning and supervision of construction projects and also functions as an intermediary between various co-developers. True, Adlershof Projekt GmbH did not emerge endogenously (as in Metcalfe's model) from all three helices, but it actively influences the formation of relations of exchange between the three helices by means of its function as trustee and development agency (Metcalfe 2010: 504, 507). It was Adlershof Projekt GmbH which, in the light of a growing shortage of housing in popular inner-city locations in Berlin, revived the original idea of developing housing in the Berlin-Adlershof science and technology park.

By initiating the workshop, Adlershof Projekt GmbH brought together all relevant actors from the different helices early in the planning process. All the experts interviewed regard Adlershof Projekt GmbH as being - throughout the planning process - the initiator and organizer of all content-related interaction and of the urban development framework, for the Wohnen am Campus project. The intermediary hypothesis (H1.3) can therefore be confirmed.

\section{Main hypothesis}

After considering the findings from the three sub-hypotheses, we have to conclude that none of the models of the triple helix represented in Figure 1 can be usefully applied, in 
its pure form, to the interaction of actors in residential development in a science and technology park. For the case study used here, it is possible to identify a one-off interaction between the three helices in relation to the development of housing. This, however, does not take place regularly, nor are the three helices involved on an equal footing.

Instead, it can be observed that selected features of the laissez-faire model are reflected in the institutional arrangements (Ranga and Etzkowitz 2013: 239, see Figure 1b). Figure 4 illustrates the adaptation of the model to the Berlin-Adlershof case study. Here the responsibilities of the actors involved in residential development are clearly defined. In the context of the urban development programme, the leading role falls to government. In addition to the model presented by Ranga and Etzkowitz (2013), an intermediary plays the key role in the planning process (Adlershof Projekt $\mathrm{GmbH}$ ). The interactions and relations of exchange between the helices are managed through this intermediary: "When there is interaction and interrelationship among the spheres, it is expected to take place across strongly defended boundaries and preferably through an intermediary" (Etzkowitz 2003: 306, emphasis added). Adlershof Projekt GmbH must therefore be seen as a pivotal actor in residential development and is pictured accordingly in Figure 4.

The outcome of the research confirms, however, that it is primarily bilateral forms of collaboration which are managed through the intermediary. A triple helix structure in its most extensive form (balanced model, see Figure 1c) can thus not be observed in the transformation process from a science and technology park to the Berlin-Adlershof science city. The main hypothesis formulated at the outset cannot be confirmed.

\section{Discussion}

The key assumption of the triple helix approach is that innovations occur through the interaction of actors from government, industry and university. This research article has examined whether the creation of housing in science cities can be explained by the interaction of actors from government, industry and university. The study has shown that the triple helix approach cannot be usefully applied to the interaction of actors involved in residential development in science cities. The reason for this is that no

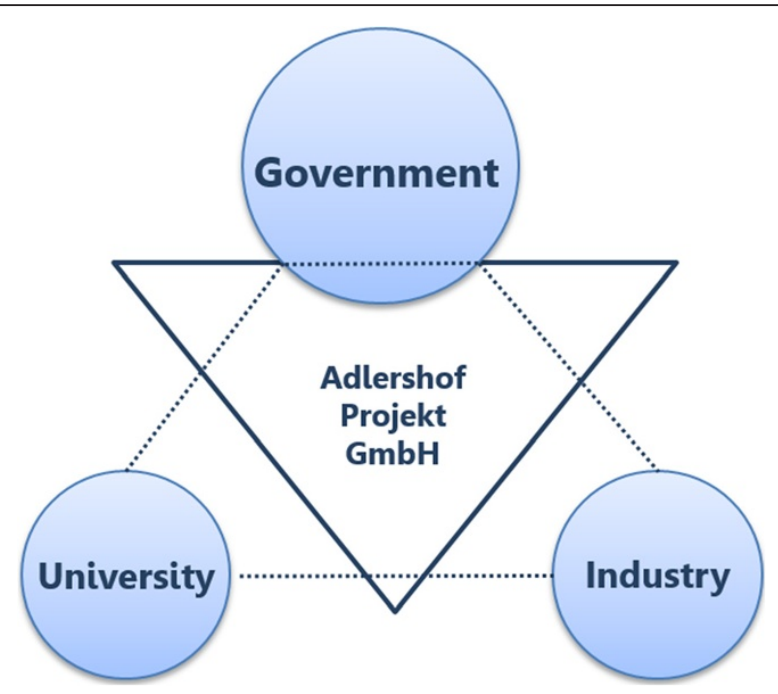

Figure 4 Interaction model of planning process for residential development based on the case study Wohnen am Campus (authors' design). 
interaction between the three helices took place in most of the relevant planning steps. Within the framework of the study, it has been possible to identify four factors inhibiting interaction, each of which has implications for the applicability of the triple helix approach to the transformation of a science and technology park into a science city through residential development.

Firstly, demand for housing is not evenly distributed across the three helices. For one, there is no need for owner-occupied housing for a large proportion of those employed here. Employees seek a functional separation of home and workplace: "No more Siemensstadt!"a . For another, the triple helix approach assumes that the three helices interact on the premise that added value will be created by this interaction; in the triple helix approach, this added value comes from innovation, which can for example open up new areas of business for industry. The local industrial actors choose not to get involved in the planning process for Wohnen am Campus because they foresee no immediate monetary benefit. Residential development is therefore not suitable as a case study for the triple helix model, because an unequal distribution of demand limits the interaction between the actors a priori.

Secondly, the Humboldt-University of Berlin is not playing an entrepreneurial role in residential development at the Adlershof site. The triple helix approach assumes entrepreneurial universities, which are often to be found in the US, with examples such as Stanford University and Massachusetts Institute of Technology (MIT) (Kitagawa 2005). The Humboldt-University of Berlin, however, cannot be described as an entrepreneurial university in relation to the business of residential development. For this, it would have to generate knowledge that could be used for residential development. As the Humboldt-University plays a subordinate role in the planning process for the Wohnen am Campus housing project, we can conclude that either it generates no knowledge which can be used for the development of housing or there is some delay or hindrance in the process by which the knowledge it generates is capitalized upon. The applicability of the triple helix concept to residential development in a European science and technology park is probably limited because the approach assumes an entrepreneurial university based on the American model.

Thirdly, the study shows that the interaction of actors involved in residential development is dependent on their resources. The triple helix approach pays little attention to resourcing, if this is taken to mean the availability of funds and personnel for generating innovation. The analysis of the expert interviews showed that the ability of the HumboldtUniversity to participate was limited by its financial and staffing resources (HU 2013, interview). At the same time it is worth considering whether the dominance of the Senate Department and Adlershof Projekt GmbH can be explained not just by their authority in terms of planning law, but also by their access to personnel and funds. The more likely it is that power derived from access to resources might influence the outcome of negotiations between actors of the helices, the more important this question becomes.

Fourthly, the importance of the intermediary must be underlined. Little attention is paid to intermediaries in the triple helix approach. Etzkowitz (2003) did touch on their role, but for a long time, "organizations that operate in the spaces between institutions of higher education, industrial firms, and government agencies" (Metcalfe 2010: 504) were ignored. The model proposed by Metcalfe (2010) - as a way of understanding intermediary organizations which do not belong to any helix - has yet to be empirically tested. Adlershof 
Projekt GmbH does fulfil intermediary functions with regard to residential development on the site, but its corporate history means that it has strong ties to the government helix (see Figure 4). It is therefore not an external organization, operating independently of the three helices, nor can it be understood, in terms of the balanced model of the triple helix (see Figure 1c), as a hybrid organization which forms endogenously as a result of the high degree to which the three helices intersect. Instead, Adlershof Projekt GmbH qualifies as the organization charged with implementing the Johannisthal/Adlershof urban development programme on behalf of the Senate Department. The organization interprets its functions as the trustee and development agency as an intermediary role between actors from the three helices who are relevant to the site, and yet thanks to the urban development programme, it has extensive planning powers over the site.

It may not be possible to ascribe any innovative content, in the terms of the triple helix concept, to the transformation from a science and technology park into a science city by means of residential development. Nonetheless, Wohnen am Campus does offer something new and innovative: the creation of housing gives the site a more urban character and could therefore indirectly encourage innovative activity. A wide range of studies have argued that a diverse urban environment can have stimulating effects on the generation of basic resources of the knowledge-based economy: innovation, creativity and knowledge (Florida 2002; Frenkel et al. 2013). In the terms of the triple helix approach, the construction of housing could thus be understood as infrastructure for innovation. Etzkowitz (2003) suggests that the focus of triple helix research should be expanded, because "instead of focusing only on the potential for product development from individual technologies, there is a broader concern with creating an infrastructure for innovation in innovation through an enhanced Triple Helix" (Etzkowitz 2003: 299 f.). However, these indirect, positive feedback effects of a housing project that gives an urban character to a science and technology park can only be studied after the project has been completed and the residents have moved in.

\section{Endnote}

${ }^{a}$ Home to production facilities as well as workers' residences, this part of the Berlin district of Spandau is known for its spatial juxtaposition of labour and leisure. Its namesake is Siemens AG (then known as Telegraphen-Bau-Anstalt von Siemens und Halske), which erected plants, housing and communal infrastructure at its own cost (Bienek 2007).

\section{Additional file}

Additional file 1: Multilingual abstracts in the five official working languages of the United Nations and Portuguese. review notes on the final draft of the manuscript. All authors read and approved the final manuscript. 
References

Bathelt H, Feldmann MP, Kogler DF (2011) Territorial and relational dynamics in knowledge creation and innovation: an introduction. In: Bathelt H, Feldmann MP, Kogler DF (ed) Beyond territory: dynamic geographies of knowledge creation, diffusion, and innovation. Routledge, London, pp 1-17

Bienek K (2007) URL: www.diegeschichteberlins.de/geschichteberlins/berlin-abc/stichworteot/631-siemensstadt.html (Accessed 05 July 2014)

Etzkowitz H (2003) Innovation in innovation. The triple helix of university-industry-government relations. Studies of Science 42(3):293-337

Etzkowitz H (2013) Anatomy of the entrepreneurial university. Soc Sci Inf 52(3):486-511

Etzkowitz H, Leydesdorff L (ed) (1997) Universities and the global knowledge economy: a triple helix of university-industrygovernment relations. Pinter, London

Etzkowitz H, Leydesdorff $L$ (2000) The dynamics of innovation: from national systems and "mode 2" to a triple helix of university-industry-government relations. Res Policy 29(2):109-123

Etzkowitz H, Zhou C (2008) Introduction to special issue: building the entrepreneurial university: a global perspective. Sci Public Policy 35(9):627-635

Etzkowitz H, Webster A, Gebhardt C, Regina B, Terra C (2000) The future of the university and the university of the future: evolution of ivory tower to entrepreneurial paradigm. Res Policy 9(2):313-330

Florida R (2002) The rise of the creative class: and how it's transforming work, leisure, community and everyday life. Basic Books, New York

Fogelberg H, Thorpenberg S (2012) Regional innovation policy and public-private partnership: the case of Triple Helix arenas in western Sweden. Sci Public Policy 39(3):347-356

Frenkel A, Bendit E, Sigal K (2013) Residential location choice of knowledge-workers: the role of amenities, workplace and lifestyle. Cities 35:33-41

Gibbons M, Limoges C, Nowotny H, Schwartzman S, Scott P, Trow M (1994) The new production of knowledge: the dynamics of science and research in contemporary societies. Sage, London

Handrich L, Pawel F, Proske S (2008) Standort Berlin-Adlershof: Krättige Impulse für die Stadt. Wochenbericht des DIW Berlin, 04/2008 41-46

Heßler M (2007) Wissenschaftsstädte - Zur Bedeutung des Topos der, kreativen Stadt' für die Wissensproduktion. Berichte zur Wissenschaftsgeschichte 30(2):145-160

Hölmer R (2013) Motor der Entwicklung im Bezirk. In: SenStadtUm (Senatsverwaltung für Stadtentwicklung und Umwelt) \& AP (Adlershof Projekt GmbH) (2013). Stadt für Wissenschaft, Wirtschaft und Medien, Berlin Adlershof, p 4

Hotz-Hart B, Rohner H (2014) Nationen im Innovationswettlauf. Ökonomie und Politik der Innovation. Springer Fachmedien, Wiesbaden

Kitagawa F (2005) Entrepreneurial universities and the development of regional societies: a spatial view of the Europe of knowledge. Higher Education Management and Policy 17(3):65-89

Kühn M (2003) Wissenschaftsstädte - Wissenschaftsparks. Raumforschung und Raumordnung 61(3):139-149

Leydesdorff $L$ (2000) The triple helix: an evolutionary model of innovations. Res Policy 29(2):243-255

Leydesdorff L (2013) Triple helix of university-industry-government relations. Encyclopedia of Creativity, Invention, Innovation and Entrepreneurship. URL: www.springerreference.com/docs/html/chapterdbid/378826.html (accessed Jan 18 2014)

Leydesdorff L, Etzkowitz H (1996) Emergence of a triple helix of university-industry-government relations. Sci Public Policy 23:279-286

Leydesdorff L, Etzkowitz H (1998) The triple helix as a model for innovation studies. Science \& Public Policy 25(3):195-203

Metcalfe A (2010) Examining the trilateral networks of the triple helix: Intermediating organizations and academyindustry-government relations. Crit Sociol 36(4):503-519

Mieg H (2012) Sustainability and innovation in urban development: concept and case. Sustain Dev 20(4):251-263

Mieg H, Mackrodt U (2010) Science and technology park management: from business integration to technology and urbanity - the case Berlin-Adlershof. In: Hollaender R, Wu C, Duan N (ed) Sustainable development of industrial parks. Logos, Berlin, pp 162-174

Müller M (2013) Erfolg als Ansporn. In: Adlershof Projekt GmbH. Adlershof Special, p 1. 31

Ortiz A (2013) Kooperation zwischen Unternehmen und Universitäten. Eine Managementperspektive zu regionalen Innovationssystemen. Springer Fachmedien, Wiesbaden

Rammert W (2007) Technik, Handeln, Wissen. Zu einer pragmatischen Technik- und Sozialtheorie. VS Verlag für Sozialwissenschaften. Wiesbaden

Ranga M, Etzkowitz H (2013) Triple Helix systems: an analytical framework for innovation policy and practice in the knowledge society. Ind High Educ 27(4):237-262

Rodriques C, Melo Al (2013) The triple helix model as inspiration for local development policies: An experience-based perspective. Int J Urban Reg Res 37(5):1675-1687

SenStadt (Senatsverwaltung für Stadtentwicklung) (2007) Städtebaulicher Entwicklungsbereich Johannisthal/Adlershof. Bilanz der Entwicklung. Berlin. URL: www.stadtentwicklung.berlin.de/bauen/entwicklungsgebiete/pdf/ JohannisthalAdlershofBilanz.pdf (accessed Mar 2, 2014)

SenStadt (Senatsverwaltung für Stadtentwicklung) (2009) Protokoll zum Workshop Wohnen am Campus vom 27.08.2009. Berlin

SenStadtUm (Senatsverwaltung für Stadtentwicklung und Umwelt) (2013a). Berlin Adlershof. Stadt für Wissenschaft, Wirtschaft und Medien. URL: www.adlershof.de/fileadmin/user_upload/downloads/SenStadtUm_Adlershof_Brosch_ 2013_Web.pdf (accessed Jan 20, 2014)

doi:10.1186/s40604-014-0010-1

Cite this article as: Bellgardt et al.: Triple helix and residential development in a science and technology park: the role of intermediaries. Triple Helix 2014 1:10. 